【論文】

\title{
残差相互スペクトルによる地震動の波形特性 \\ WAVE CHARACTERISTICS OF EARTHQUAKE GROUND \\ MOTION BY RESIDUAL CROSS SPECTRA
}

\author{
星 谷勝* - 石橋裕** \\ By Masaru HOSHIYA and Yutaka ISHIBASHI
}

\section{1. まえがき}

多次元非定常確率過程の理論構成を物理的意味を明ら かにするために分解してみると, Bendat ${ }^{4)}$, Dodds 等 ${ }^{6)}$ の残差相互スペクトル（または, 残差コヒーレンス）が 理論の中心的な役割を果していることが明らかとなっ た ${ }^{1)}$ こここでは, この残差相互スペクトルを用いて強震 地震動の加速度波形特性の解明を試みたものである。ま ず，2. 残差相互スペクトルの物理的意味を検討し， 3. 残差コヒーレンスを用いて特徴のわかった人工地震動 3 成分の波形特性の相互相関性を解析し, 残差コヒーレン スによってその特徴をとらえることのできることを確認 した。そして 2，3 の結果を踏えて, 先の研究 ${ }^{2)}$ で扱っ た実地震加速度波 (Hollwood Storage 記録) の 1 点 3 成分波の波形特性を解析し，実体波や表面波の検出に残 差コヒーレンスが有用であることを示唆した.

\section{2. 残差相互スペクトルの物理的意味の検討}

\section{（1）残差相互スペクトル}

多次元非定常確率過程のシミュレーション理論 ${ }^{3)} に よ$ れば

$$
x_{i}(t)=\sum_{p=1}^{i} \sum_{k=1}^{N} b_{i p}\left(\omega_{k}, t\right) \cos \left\{\omega_{k} t+\beta_{i p}\left(\omega_{k}, t\right)+\varphi_{p k}\right\}
$$

ここで, $b_{i p}(\omega, t), \beta_{i p}(\omega, t)$ は次式のように $S_{i j}(\omega, t:$ w）を分解して与えられる.

$$
S_{i j}(\omega, t: w)=\frac{1}{4 \Delta \omega} \sum_{p=1}^{i} B_{i p}(\omega, t) B_{j p} *(\omega, t)
$$

\footnotetext{
* 正会員 Ph.D. 武藏工業大学教授 土木工学科

** 八千代エンジニヤリング（株）技術本部
}

$$
\begin{aligned}
& B_{i p}(\omega, t)=b_{i p}(\omega, t) \exp \left\{i \beta_{i p}(\omega, t)\right\} \\
& \Delta \omega=\left(\omega_{U}-\omega_{L}\right) / N, \omega_{k}=\omega_{L}+\left(k-\frac{1}{2}\right) \Delta \omega \\
& \varphi_{p k}: 0 \sim 2 \pi \text { の一様乱数 }
\end{aligned}
$$

なお， $\omega_{U}, \omega_{L}$ は $S_{i j}(\omega, t: w)$ が有意強度を持つ正 の $\omega$ 領域の上限值および下限值である. $N$ は十分に大 きな整数とする.

ここで，式（1）は次式のように分解されよう.

$$
\begin{aligned}
& a_{p}(t)=\sum_{k=1}^{N} \cos \left(\omega_{k} t+\varphi_{p k}\right) \\
& x_{i p}(t)=\sum_{k=1}^{N}\left|B_{i p}\left(\omega_{k}, t\right)\right| \cos \left\{\omega_{k} t+\beta_{i p}\left(\omega_{k}, t\right)+\varphi_{p k}\right\} \\
& x_{i}(t)=\sum_{p=1}^{i} x_{i p}(t)
\end{aligned}
$$

式 (3) は $\omega_{L} \leqq \omega \leqq \omega_{U}$ 領域でパワースペクトル $S_{a_{p}}$ がー 定 $(1 / 4 \Delta \omega)$ の有帯域ホワイトノイズである. 式 (4) は ホワイトノイズ $a_{p}(t)$ がフィルター $B_{i p}(\omega, t)$ に入力 したときの出力となっている. 式 (5) は式 (4) の出力 を $p=1$ から $i$ まで加算したものである. したがって， 式（1）は 図一1 のように地震動は互いに独立なホワイ トノイズ $a_{i}(t)$ がある非定常なシステムを通って出力さ れた応答量と考えることができる.

そこで, 式 (1) や図一1 より出力 $x_{i}(t)$ と $x_{j}(t)$

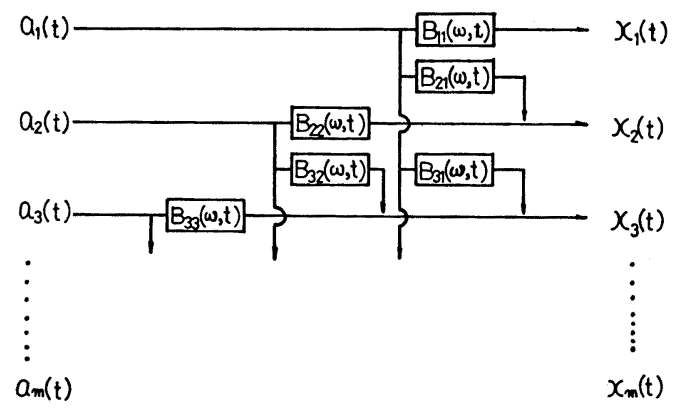

図一1 入出カシステム 
の相互スペクトルを次のように分解することが可能とな る.

$$
\begin{aligned}
S_{i j}(\omega, t: w) & =\frac{1}{4 \Delta \omega} \sum_{p=1}^{i} B_{i p}(\omega, t) B_{j p} *(\omega, t) \\
& =\sum_{p=1}^{i} B_{i p} \cdot B_{j p} * \cdot S_{a_{p}}
\end{aligned}
$$

これより $S_{i j}$ はホワイトノイズ $a_{p}(t): p=1 \sim i$ の影 響を受けた各要素の総和から構成されることがわかる.

たとえば, $x_{3}(t)$ に関しては

$$
\begin{aligned}
S_{33} & =\frac{1}{4 \Delta \omega} \sum_{p=1}^{3}\left|B_{3 p}\right|^{2} \\
& =\left|B_{31}\right|^{2} S_{a_{1}}+\left|B_{32}\right|^{2} S_{a_{2}}+\left|B_{33}\right|^{2} S_{a_{3}} \\
& =r_{13}^{2} S_{33}+r_{23,1}^{2} S_{33,1}+S_{33,12} \ldots \ldots \\
& =r_{13}^{2} S_{33}+S_{33,1} \ldots \ldots \ldots \ldots \ldots \ldots \ldots \ldots
\end{aligned}
$$

式 (6) は $x_{1}(t)$ または $x_{2}(t)$ に対して共通な $x_{3}(t)$ のエネルギー（第 1,2 項）に対して, それらとは独立 な新たなエネルギー $S_{33,12}$ を加えるものである. あるい は式 (7) から $x_{1}(t)$ に対して共通なエネルギー $\gamma_{13}{ }^{2} S_{33}$ に対して, それとは独立な新たなエネルギー $S_{33,1}$ を加 えたものといえる. $S_{33,12}$ は $x_{1}(t)$ および $x_{2}(t)$ の影響 を除去した $x_{3}(t)$ の残差 Physical Spectrum と呼ぶこ とにする.

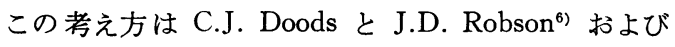
J.S. Bendar(4),5) に基ゔくものであり, 一般に J.S. Bendat") によって次のような公式が与えられている.

$$
\begin{gathered}
S_{i j, 1}=\frac{S_{11} S_{i j}-S_{i 1} S_{1 j}}{S_{11}} \quad i=2, \cdots, m \cdots \cdots(8 \\
S_{i j, 12}=\frac{S_{22,1} S_{i j, 1}-S_{i 2,1} S_{2 j, 1}}{S_{22,1}} \quad i=3, \cdots, m \\
i \leqq j \cdots \cdots \cdots \cdots \cdots \cdots \cdots(9
\end{gathered}
$$

(J.S. Bendat は 定常過程の場合を示しているが非定 常過程に容易に拡張できる)

そこで， $x_{2}(t)$ および $x_{3}(t)$ から $x_{1}(t)$ の影響を除 去した残差相互スペクトルは

$$
S_{23,1}=\frac{S_{11} S_{23}-S_{21} S_{13}}{S_{11}}=\frac{1}{4 \Delta \omega} B_{22} B_{32} * \cdots \cdots(10)
$$

となる。

さて, 次のような要素からなる地震動 3 成分を考えて みよう。

$$
\begin{aligned}
& x_{1}(t)=y_{11}(t)+y_{12}(t)+y_{13}(t) \\
& x_{2}(t)=y_{21}(t)+y_{22}(t)+y_{23}(t) \\
& x_{3}(t)=y_{31}(t)+y_{32}(t)+y_{33}(t)
\end{aligned}
$$

ここで, $y_{12}(t)$ と $y_{21}(t)$ は完全相関しているものと する. 同様に $\left\{y_{13}(t)\right.$ と $\left.y_{31}(t)\right\}$ および $\left\{y_{23}(t)\right.$ と $y_{32}$ $(t)\}$ はそれぞれ完全相関したグループとする. 一方, $y_{11}(t), y_{22}(t)$ および $y_{33}(t)$ は互いに独立で, かつ他の $y_{12}(t), y_{13}(t) \cdots$ 等とも独立であるとする. このように して構成された $x_{1}(t), x_{2}(t), x_{3}(t)$ を式 (1) よりシミ ュレートすれば

$$
\begin{aligned}
& x_{1}{ }^{\prime}(t)=Y_{11}(t) \\
& x_{2}{ }^{\prime}(t)=Y_{21}(t)+Y_{22}(t) \\
& x_{3}{ }^{\prime}(t)=Y_{31}(t)+Y_{32}(t)+Y_{33}(t)
\end{aligned}
$$

となる. 寸なわち, 最初のプロセス $x_{1}(t)$ は 1 つの項よ り構成され $x_{1}{ }^{\prime}(t)$ となる. 第 2 のプロセス $x_{2}(t)$ は 2 つの項から構成されてシミュレートされる. 第 3 のプロ セスは同様にして 3 つの項から構成されることになる. その結果, たとえば第 3 式は元の構成要素を示すが, 第 2 式の $Y_{22}(t)$ および第 1 式の $Y_{11}(t)$ は元の構成要素 ではなく実際は $Y_{22}(t)=\left\{y_{22}(t)+y_{23}(t)\right\}$ と $Y_{11}(t)=$ $\left\{y_{11}(t)+y_{12}(t)+y_{13}(t)\right\}$ と考えられる。

したがって, 地震動成分を構成要素に分解して調べる ためには, 各成分の解析順序を入れ換えて式 (1) をそれ ぞれに対して計算する必要がある. いいかえれば，おの おのの波の構成要素を明らかにするために相互スペクト ル行列の入れ換えが必要となる.

以上の考え方を実証するために, あらかじめ特徴のわ かった波で残差相互スペクトルを求めてみることにす る.

\section{（2）人工地震波による残差相互スペクトルの検討}

\section{（a）人工地震波}

残差相互スペクトルマップを正しく解釈するために， あらかじめ特徴の明白なかつ, もっとも単純な波を用い て検討する. そのために，人工地震波 $x_{i}(t), i=1,2,3$ は次のようにして作成した.

まず, 平均值 0 のホワイトノイズが伝達関数 $H_{i}(\omega)$ に入力したときの定常応答量 $y_{i}(t)$ を $i=1$ から 3 まで 互いに独立として, 次のように作成する.

$$
y_{i}(t)=\sum_{k=1}^{N}\left|H_{i}\left(\omega_{k}\right)\right| \cos \left\{\omega_{k} t+\theta_{i}\left(\omega_{k}\right)+\varphi_{i k}\right\}
$$

ただし, $H_{i}(\omega)=f_{i}(\omega) \exp \{i \theta(\omega)\}$

ここで, $f_{i}(\omega)$ は $y_{i}(t)$ のスペクトル強度分布がは っきり現われるようにするために

$$
f_{i}(\omega)=10 \cdot e^{-2\left|\omega-\omega_{0}\right|}
$$

ただし, $\omega_{0}: H_{i}(\omega)$ の周波数特性値

の関数で与えた. $f_{i}(\omega)$ の関数形は 図一2 のよ5にな る.また, 位相角 $\theta_{i}(\omega)$ は任意に与える.

さて，これらの $y_{i}(t)$ を用いて解析に使用する人工 地震波を次のようにして作成した.

$$
\begin{aligned}
& x_{1}(t)=y_{1}(t) \cdots \cdots \cdots \cdots \cdots \\
& x_{2}(t)=y_{1}(t)+y_{2}(t) \cdots \cdots \cdots \cdots \\
& x_{3}(t)=y_{1}(t)+y_{2}(t)+y_{3}(t)
\end{aligned}
$$

ここで, 3 個の独立波 $y_{i}(t), i=1,2,3$ の性質を表一1 に示しておく.この人工地震波構成からわかるように， $x_{i}(t)$ と $x_{j}(t)$ の相互スペクトルはそれぞれ共通に有す る構成要素の Physical Spectrum の和となり位相差は 


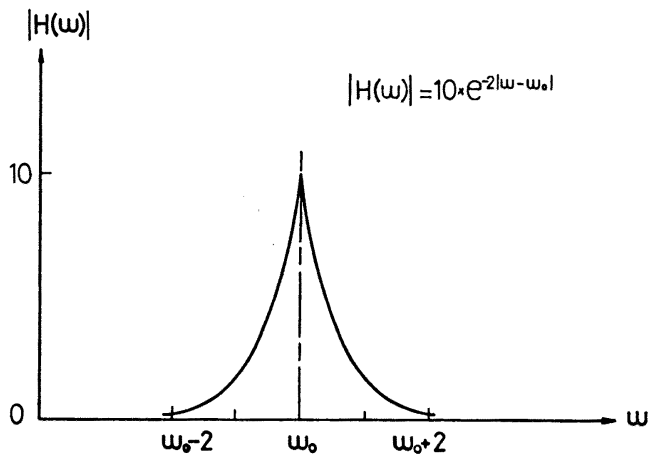

图-2 $\boldsymbol{f}(\boldsymbol{\omega})=|\boldsymbol{H}(\boldsymbol{\omega})|$ の関数形

表一1 人工地覆波の特性

\begin{tabular}{c|c|c|c}
\hline & $\begin{array}{c}\text { 含有周波数領域幅 } \\
(\mathrm{Hz})\end{array}$ & $\begin{array}{c}\text { 周波数特性值 } \\
(\mathrm{Hz})\end{array}$ & 位 相 角 \\
\hline$y_{1}$ & $0.0 \sim 5.0$ & 2.0 & $30^{\circ}$ \\
$y_{2}$ & $1.5 \sim 6.5$ & 4.0 & $30^{\circ}$ \\
$y_{3}$ & $3.5 \sim 8.5$ & 6.0 & $30^{\circ}$ \\
\hline
\end{tabular}

常に 0 となる. たとえば, $x_{2}(t)$ と $x_{3}(t)$ の相互スペク トルは式 (14) と式 (15) より $y_{1}(t)$ の Physical Spectrum と $y_{2}(t)$ の Physical Spectrum の和となってい る. そのため, 位相角 $\theta_{i}(\omega)$ は任意に与えても本質的 にはここでの目的に影響を及ぼさない．

そこで,この人工地震波を用いて残差相互スペクトル を調べることにする.

（b）人工地震波の残差相互スペクトル

上記の人工地震波は定常であるが, 現象を明確に表示 できるように非定常な数值解析と同一の処理を行った.

多次元非定常確率過程 の相互 スペクトルを求め, 式 （2）および式（8）から式（10）の計算をすることにより 残差相互スペクトルを求める. なお, それらのマップを 図一3 加 図一8 亿示す.

まず, $x_{3}(t)$ の Physical Spectrum は

$$
S_{33}=S_{y_{1}}+S_{y_{2}}+S_{y_{3}}=\frac{1}{4 \Delta \omega}\left(\left|H_{1}\right|^{2}+\left|H_{2}\right|^{2}+\left|H_{3}\right|^{2}\right)
$$

ただし, $S_{y_{i}}: y_{i}(t)$ の Physical Spectrum

で表わされる. $x_{3}(t)$ の Physical Spectrum マップ (図 一3）は横軸を周波数軸に, 繸軸を時間軸とした。 また, 影の領域が最大スペクトル強度の $10 \%$ 以上領域を示し ている. 数值解析に含まれる誤差量を考えた上でながめ てみれば，この図は期待されたとうりの定常なマップと なっている. 図一4 は $S_{33,1}$ の解析マップであるが， $x_{1}$ ( $t$ ）の影響である $2 \mathrm{~Hz}$ を中心とする分布の帯が消えて いることが確認できる. 次に, $S_{33,12}$ の解析マップ (図 一5) から $2 \mathrm{~Hz}$ および $4 \mathrm{~Hz}$ を中心とする分布の帯が 消えていることが確認される．除去された分布の帯は $x_{1}(t)$ と $x_{2}(t)$ の影響部分である.

次に， $x_{2}(t)$ に関するスペクトルマップを検討してみ
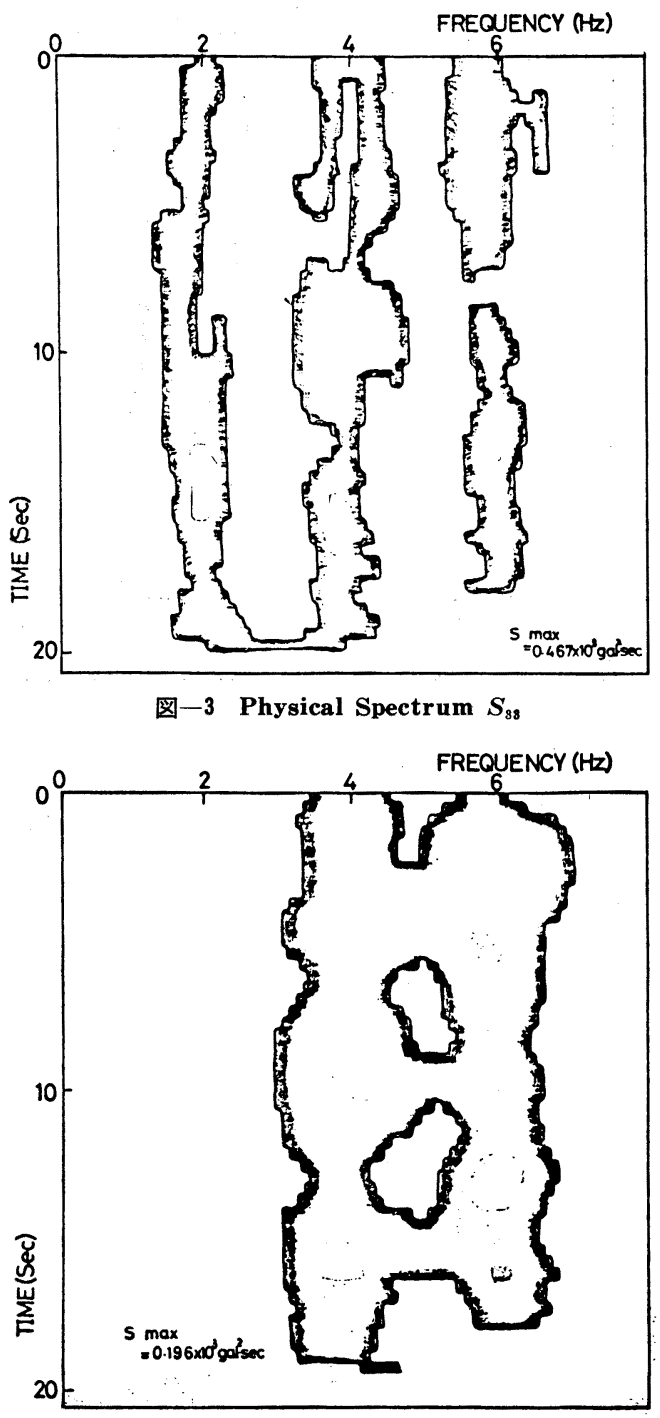

図-4 残差 Physical Spectrum $S_{33,1}$

よう。まず， $x_{2}(t)$ と $x_{3}(t)$ の相互スペクトルマップを 図一6 に示すが，期待どおり $2 \mathrm{~Hz}$ および $4 \mathrm{~Hz}$ を中心 とした分布の帯になっている. 図一7，8 はそれぞれ $S_{22,1}$ および $S_{23,1}$ の解析マップであるが， $x_{1}(t)$ の影響 である $2 \mathrm{~Hz}$ 中心の分布の帯が消えている. また， $S_{22,1}$, $S_{23,1}$ の最大スペクトル強度掞よび 分布形状がほぼ一致 し, 理論どおりに $S_{22,1}=S_{y_{2}}, S_{23,1}=S_{y_{2}}$ となっている ことがわかる。

以上のことより, 注目地震動 2 成分から他の影響成分 を除く残差相互スペクトルの解釈の正しさが明らかにさ れたと考える.さらに，これらを正規化したコヒーレン ス（残差コヒーレンス）を用いれば波形特性をより明確 にとらえることができると思われるので, 次に人工地震 波のデータを用いて残差コヒーレンスマップの検証を行 うことにする。 


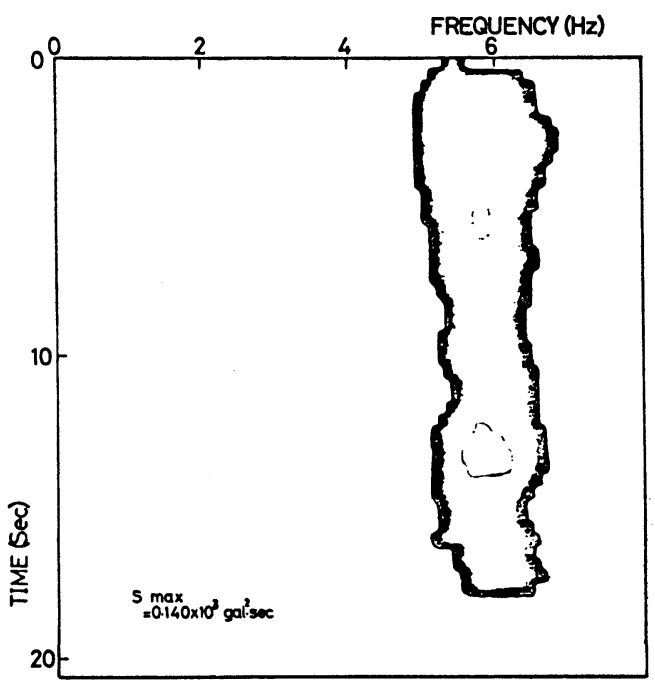

図一5 残差 Physical Spectrum $S_{88,12}$

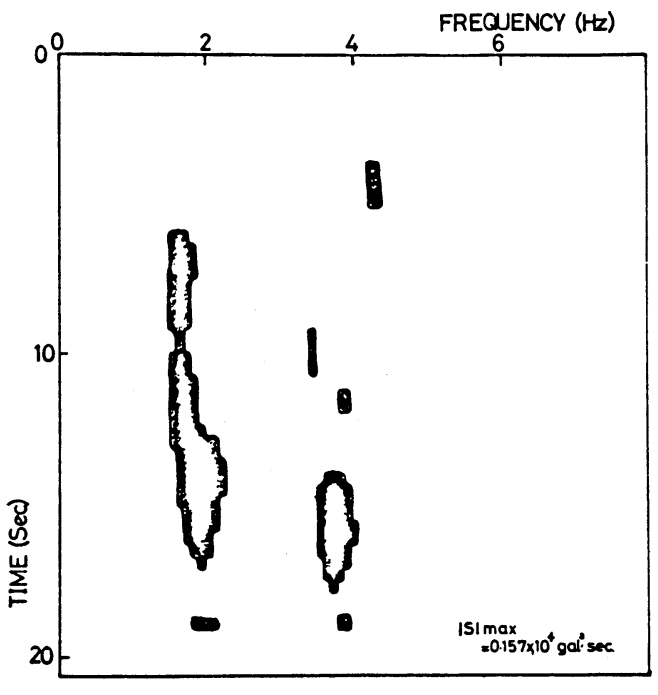

図一6 相互スペクトル $\left|S_{28}\right|$

\section{3. 残差コヒーレンスによる人工地震動 3 成分} の波形特性の解析

地震動を 3 次元のベクトルと考えた場合，長周期成分 に限定してベクトルの变動平面がわかれば表面波の種類 を検出できよう。

（1）人工地震波によるコヒーレンスマップの検討

人工地震波は高相関領域の時間的推移を追跡すること

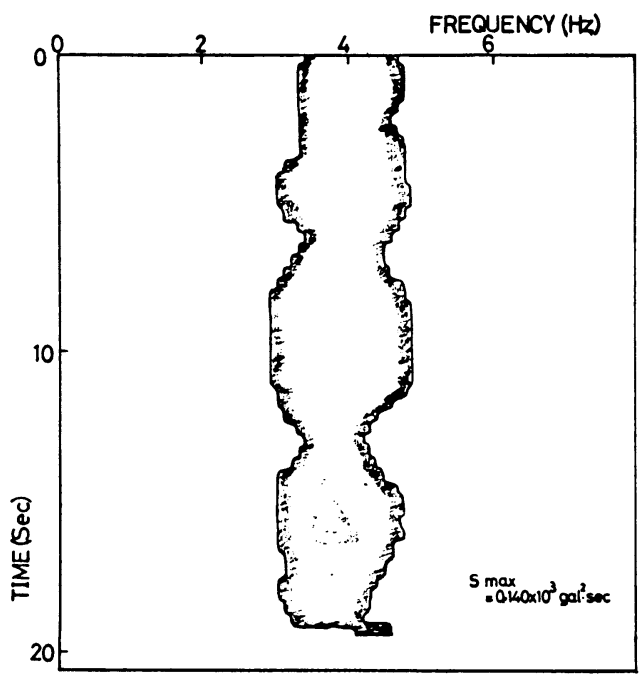

図一7 残差 Physical Spectrum $S_{22,1}$

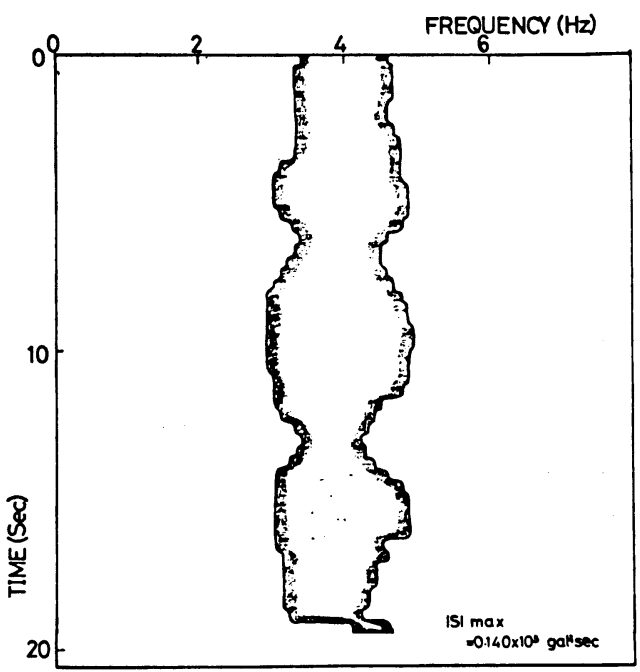

図一8 残差相互スペクトル $\left|S_{28,1}\right|$

によって，地震動ベクトルの変動平面が想定できるよう な 3 成分とした. その人工地震動 3 成分のコヒーレンス および残差コヒーレンスマップを作成する.

\section{(a) 人工地震波}

簡単のために, 人工地震波には式 (11) および式 (12) を用いて作成した定常過程の組み合せから構成される非 定常波を採用することにした，そこで，おのおのの特定 時間領城で卓越する 9 波の独立波を作り, 合成すること によって 3 波の非定常合成波とした. その 3 波の合成人 工地震波は次のようである.

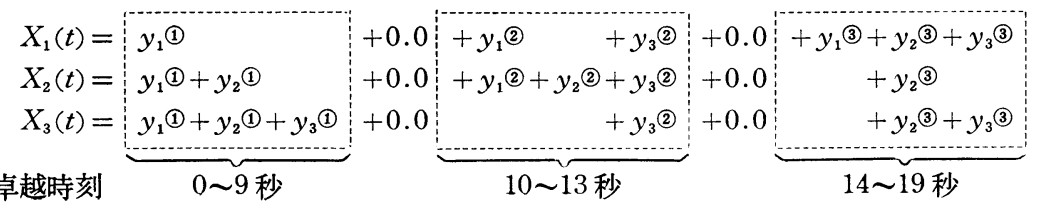


表一2人工地震波の特性

\begin{tabular}{|c|c|c|c|c|c|}
\hline & 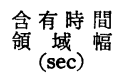 & $\begin{array}{c}\text { 含有周波数 } \\
\text { 領 域 幅 } \\
(\mathrm{Hz})\end{array}$ & $\begin{array}{c}\text { 周波数 } \\
\text { 特性 } \\
(\mathrm{Hz})\end{array}$ & 位相角 & \\
\hline$y_{1}$ (1) & $0.0 \sim 9.0$ & $0.0 \sim 5.0$ & 3.0 & $90^{\circ}$ & \\
\hline$y_{2}$ (1) & $0.0 \sim 9.0$ & $0.0 \sim 2.0$ & 0.3 & $30^{\circ}$ & 注目成分 \\
\hline$y_{3}$ (1) & $0.0 \sim 9.0$ & $0.0 \sim 8.0$ & 5.0 & $60^{\circ}$ & \\
\hline$y_{1}$ (2) & $10.0 \sim 13.0$ & $0.0 \sim 2.0$ & 0.3 & $30^{\circ}$ & 注目成分 \\
\hline$y_{2}$ (2) & $10.0 \sim 13.0$ & $0.0 \sim 8.0$ & 6.0 & $60^{\circ}$ & \\
\hline$y_{3}$ (2) & $10.0 \sim 13.0$ & $0.0 \sim 5.0$ & 3.0 & $90^{\circ}$ & \\
\hline$y_{1}(3)$ & $14.0 \sim 19.0$ & $0.0 \sim 8.0$ & 7.0 & $60^{\circ}$ & \\
\hline$y_{2}$ (3) & $14.0 \sim 19.0$ & $0.0 \sim 5.0$ & 3.0 & $90^{\circ}$ & \\
\hline$y_{3}$ (3) & $14.0 \sim 19.0$ & $0.5 \sim 2.0$ & 0.3 & $30^{\circ}$ & 注目成分 \\
\hline
\end{tabular}

なお, 添字 (i); $i=1,2,3$ は卓越時間領域のグループを 示している. たとえば，(1) は卓越時刻 $\{0 \sim 9$ 秒 $\}$ のグル ープ, 同様に (2) は $\{10 \sim 13$ 秒 $\}$, (3) は $\{14 \sim 19$ 秒 $\}$ の卓 越時刻グループを示す. また, グループ間同士は互いに 独立である.

ここで, 各構成要素 $y_{i}^{(1)}, y_{i}^{(2)}, y_{i}^{(3)} i=1,2,3$ の性 質を表一2 亿示す.

この合成人工地震波は, $t=0 \sim 9$ 秒間では $X_{i}(i=1,2$, 3) を相関ゔける要素 $y_{1}{ }^{1}$, と $X_{i}(i=2,3)$ を相関づけ る要素 $y_{2}{ }^{\circledR}$, および $X_{3}$ のみの要素 $y_{3}{ }^{(1)}$ からなる波と し，相関性の循環を考えて $t=10 \sim 13$ 秒および $14 \sim 19$ 秒にそれぞれ異なる要素を組み込んだ. なお， 3 つの時 間区間を明確に分離するために, それぞれ 1 秒間にわた って $X_{1} \sim X_{3}$ の值を 0.0 としてある.

表一2 を参照すれば, これらは注目成分波（周期 0.5 秒以上）ベクトルが，0 9 秒間で $X_{2}$ 成分方向と $X_{3}$ 成 分方向の作る面内で 変動することになる. 10〜13 秒間 は $X_{1}$ 成分方向と $X_{2}$ 成分方向の作る面内で, それ以後 は $X_{1}$ 成分方向と $X_{3}$ 成分方向の作る面内で変動すると 考えてよい.

このようにして作られた合成人工地震波を次式を使っ て解析する.

式（8）を正規化して，残差コヒーレンスは

$$
r_{i j, 1}^{2}=\frac{\left|S_{i j, 1}\right|^{2}}{S_{i i, 1} \cdot S_{j j, 1}}(i \leqq j)
$$

となる.

さて,ここでの波は 3 次元波であるから $X_{2,1}$ と $X_{3,1}$ の残差コヒーレンスは

$$
r_{23,1}^{2}=\frac{\left|S_{23,1}\right|^{2}}{S_{22,1} \cdot S_{33,1}}=\frac{\left|B_{22} B_{32} *\right|^{2}}{\left|B_{22}\right|^{2}\left(\left|B_{32}\right|^{2}+\left|B_{33}\right|^{2}\right)}
$$

で計算されるが， $r_{12,3}^{2}, r_{13,2}^{2}$ 等はこの式を循環して使用 することにより計算される.

\section{(b) 人工地震波の解析}

人工地震波 $X_{1}, X_{2}$ および $X_{3}$ を 図一9 に示す.人 工地震波は時間方向で不連続であるが, 全体的な流れを 考える場合解析目的への影響はそれほどないと思われ る.
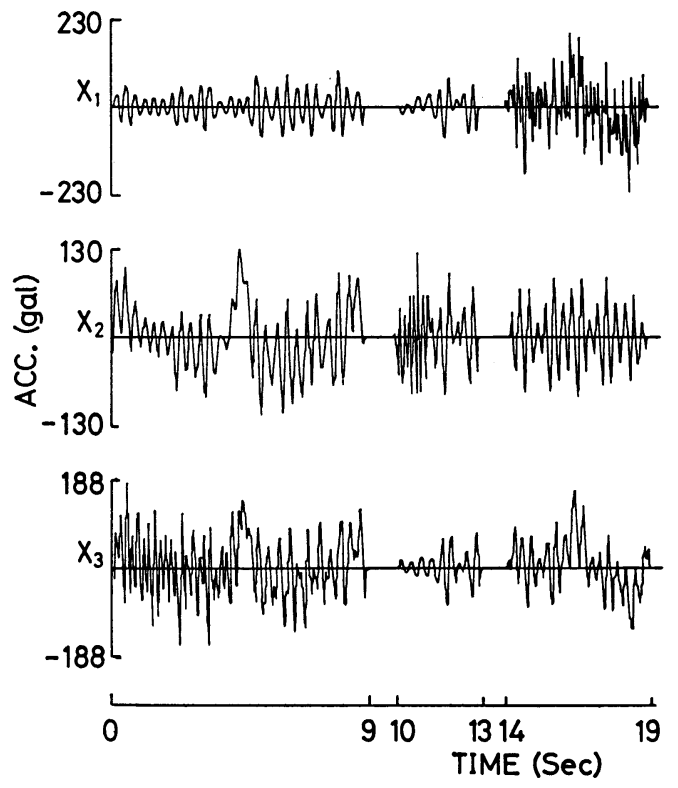

図一个人工地震波 $X_{1}, X_{2}, X_{8}$

また, 残差コヒーレンスを求めるにあたっては解析上 の誤差等によりスペクトル強度の小さい領域で高い相関 を持つ場合が生ずる. そこで, 残差コヒーレンス式の分 子の絶対残差相互スペクトル強度がきわめて小さな值と なる領域の相関度を 0 とした.

解析結果を 図一10，11 亿示寸. 与えた情報に従って $0 \sim 2 \mathrm{~Hz}$ 領域で各成分間の高相関領域の時間的推移がわ かるように表わすことができた. また, オリジナルコヒ ーレンスマップに比べて, いっそう明瞭な残差コヒーレ ンスマップを表わすことができた. ただ, どの組み合せ の残差コヒーレンスマップとも 9 10 秒付近と 13〜14 秒付近に高い相関を示す領域が存在する. これは人工地 震波を合成するとき, 人工地震波の値を 0 亿置いた部分 である. 人工地震波の值が 0 の情報だけで, その他何ん の情報も与えなかったことが高い相関を生じさせる原因 となったと思われる.

なお, 全体のマップを通して, 時刻の初期と最終期の 值は, 時刻の中間期の解析精度に比べて解析精度が悪く なっているので, 与えられた相関度を忠実に表わしてい ないと考えられる.

図一10 はオリジナルコヒーレンスマップ $r X_{1} \cdot X_{2}, r X_{1} \cdot X_{\mathrm{s}}$ および $r X_{2} \cdot x_{3}$ である. 横軸は周波数軸, 縦軸は時間軸 とした. そして, 影の部分がコヒーレンス值 0.8 以上 となる領域を示している. 注目周波数領域 $(0 \sim 2 \mathrm{~Hz})$ で は, $t=0 \sim 10$ 秒頃まで $r x_{2} \cdot x_{2}$ の相関が高く, 10 13 秒 間で $r X_{1} \cdot x_{2}$ の相関が高い.そして, 13 秒以後は $r X_{1} \cdot x_{3}$ の相関が高い. 一方, 注目周波数領域の上述以外の時間 帯では相関が低くなっている. 注目周波数領域以外 (2 


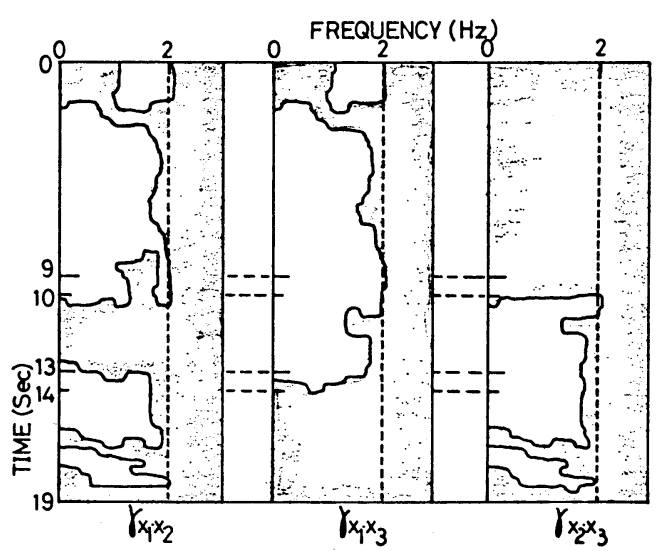

図一10人工地震波のオリジナルコヒーレンス

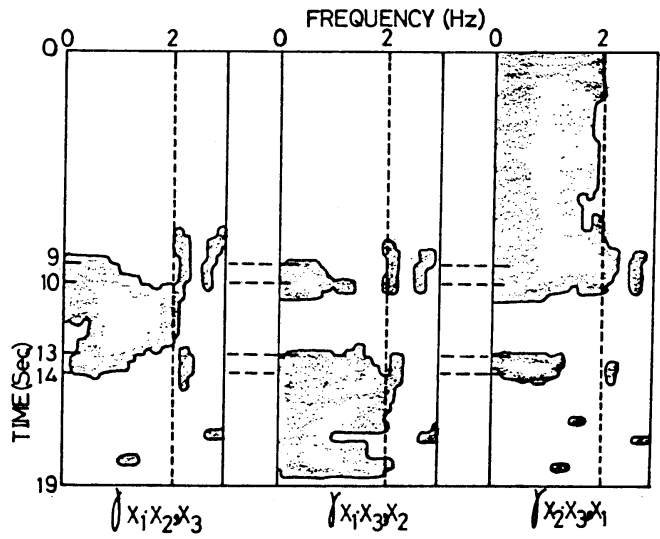

図一11人工地震波の残差コヒーレンス

$\sim 3 \mathrm{~Hz})$ の相関は高い．以上の観察結果は人工地震波を そのように作ったわけであるから当然のことといえる. 次に, 残差コヒーレンスマップ（図一11）であるが, 注目周波数 - 注目時刻 $\left(\tau X_{1} \cdot X_{3}, X_{3} ; 10 \sim 13\right.$ 秒 $\cdot \gamma X_{1} \cdot X_{3}, X_{2}$; $14 \sim 19$ 秒 $\cdot \gamma X_{2} \cdot x_{2}, X_{1} ; 0 \sim 9$ 秒) 領域以外の相関はきわ めて低く, 注目 2 成分から他の 1 成分の影響が除去され た相関分布となっている.

2, 3 よりあらかじめ特徴のわかった人工地震波によ って，残差相互スペクトルの物理的意味を明らかにし， 与えた情報どうりの相関度を残差コヒーレンスマップに よって明膫に示すことができた.これは逆にコヒーレン スマップから相関度を知り, 地震加速度ベクトルの変動 平面推定の可能性を示したことにならう。よって, 実地 震波のコヒーレンスマップの 長周期領域（周期 1 秒以 上）内で高相関領域の推移を追跡することによって, 表 面波成分の検出が可能となろう.このとき残差コヒーレ ンスを適用して,オリジナルコヒーレンスマップよりも 明瞭なマップが作成できるならば波形特性を明瞭に抽出 できると思われる。

\section{4. 実地震波への適用}

先の研究 ${ }^{2}$ で, Hollywood Storage 記録 (1971 年 2 月, サンフェルナンド地震) の地震加速度波の波形特性 を主軸II方向（相互スペクトルを周波数領域および時間 領域で積分したものを要素とする行列を対角化する主 軸）で, 地震動 3 成分の相関性および相互スペクトル強 度の分布状態から表面波らしきものを抽出した（すなわ ち, 時刻 10 秒から 13 秒にかけて Rayleigh 波が成長 し，それ以降で Love 波が成長していると推論したもの である)。そこで，主軸而方向の地震加速度波の残差相 互スペクトルおよび残差コヒーレンスを $0 \sim 1 \mathrm{~Hz}$ の周 波数領域帯で求め, あらためて先の研究での波形特性の 観察について検討する.

なお, Hollywood Storage 記録の主軸II方向は，地震 動の入射方向と考えられる方向 ( $5^{\prime}$ 軸) と, それに直角 な方向 ( $4^{\prime}$ 軸) およびこれら 2 方向軸の作る平面に垂直 な方向 (6' 軸) となっている. $6^{\prime}$ 軸と鉛直方向とのなす 角度が $7^{\circ}$ 程度である.

実地震波成分の相関度は, 高相関領域である限り, オ リジナルコヒーレンスでも残差コヒーレンスでも相関度 には差違がない，しかし，低相関領域では，オリジナル コヒーレンスよりも，残差コヒーレンスの方が高い相関 度を示すであろう。これは, 注目 2 成分から他の影響 1 成分を除去する操作からも容易に想定できよう。そこ

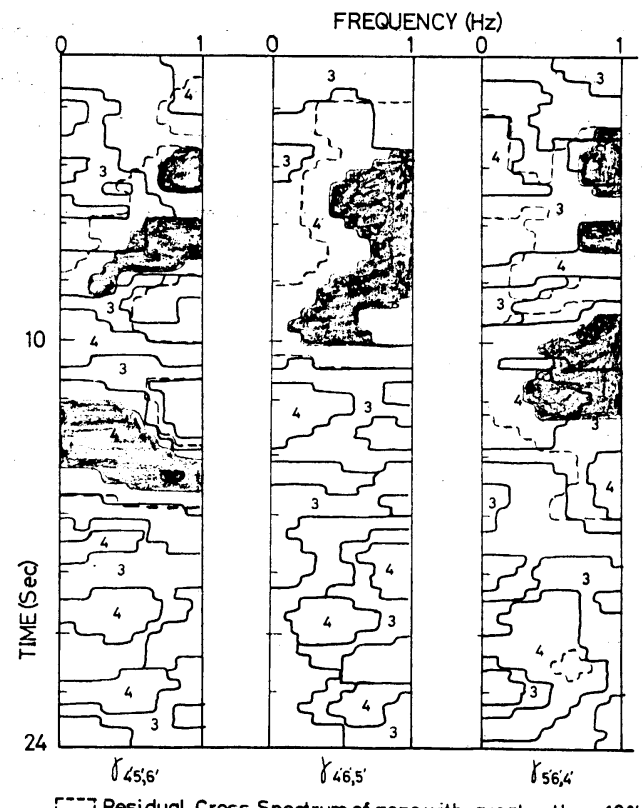

$[=--]$ Residual Cross Spectrum of zone with greater than $10 \%$ - Residual Cross Spectrum of zone with greater than $30 \%$

図-12 残差コヒーレンス（主軸 II)-Hollywood
Storage 記録 
で，残差コヒーレンスから波形特性を観察する場合には スペクトル強度との関係に注意する必要がある。すなわ ち, 注目周波数領域で相関度が高く，かつ残差相互スペ クトル強度の高い領域を観察すればよい.

図一12に $\gamma_{4^{\prime} \cdot 5^{\prime}, 6^{\prime}}, r_{4^{\prime} \cdot 6^{\prime}, 5^{\prime}}$ および $\gamma_{5^{\prime} \cdot 6^{\prime}, 4^{\prime}}$ の残差コヒ ーレンスマップを示す. なお, 添字は主軸II方向での地 震加速度波成分を示している. マップは, 残差コヒーレ ンス值 0.8 以上領域を “4”, 0.6 以上領域を “ 3 ” とし, それ以下の領域は無記入とした. また, 絶対最大残差相 互スペクトル強度の $10 \%$ 以上領域を破線で, $30 \%$ 以上 領域を影で示した. スペクトル強度を考慮すると, $t=3$ $\sim 10$ 秒で $r_{4^{\prime} \cdot 6^{\prime}, 5^{\prime}}, 9 \sim 13$ 秒間は $r_{5^{\prime} \cdot 6^{\prime}, 4^{\prime}}$ そして $12 \sim 16$ 秒にかけて $\gamma_{4^{\prime} \cdot 5^{\prime}, 6^{\prime}}$ と高相関領域を追跡することができ る. 先の研究のように地震動ベクトルの変動平面を考え ると, $t=3 \sim 10$ 秒にかけてせん断的な波が卓越し, 9 秒 以降表面波の成長が考えられる. この表面波は，9〜13 秒間は Rayleigh 波が卓越し，12 秒頃からそれ以降 Love 波の卓越があると推定できる.

残差コヒーレンスがオリジナルコヒーレンスに比べ て, より忠実に注目成分間のみの相関性をとると考える から, この節での Hollywood Storage 記録の地震加速 度波の波形特性の観察結果に対する確実度が上ったと考 えられる. したがって, 先の研究での観察は妥当な結果 といえよう。

\section{5. あとがき}

（1）あらかじめ特徴のわかった人工地震波の解析に よって, 残差相互スペクトルおよび残差コヒーレンスの 物理的意味を確認することができた.

（2）このことは, 多次元非定常確率過程のシミュレ ーション理論が妥当なものであることの検証となった.

（3）残差コヒーレンスによって，人工地震波に与え られている特徴を抽出することができた.

（4）実地震動の加速度波形特性をとらえるには残差 コヒーレンスが有用である.

以上, 残差相互スペクトルの物理的意味を明らかにす るとともに，その有用性を示したものである.

\section{参 考 文 献}

1) 星谷: 多次元確率過程のシミュレーション理論の物理的 意味について, 土木学会論文報告集, 第 270 号, 1978 年 2 月

2）星谷・石橋 : 地震動ベクトルの主軸と波形特性, 土木学 会論文報告集, 第 268 号, 1977 年 12 月

3）星谷：多次元非定常確率過程の相互スペクトルとシミュ レーション理論, 土木学会論文報告集, 第 253 号, 1976 年 9 月

4) J.S. Bendat : Solutions for the Multiple Input/Output Problem, Journal of Sound and Vibration, 1976, 44 (3), 311-325

5） J.S. ベンダット, A.G. ピアソル：ランダムデータの統 計処理, 培風館, 昭和 51 年

6) C.D. Dodds and J.D. Robson : Partial Coherence in Multivariate Random Processes, Journal of Sound and Vibration, 1975, 42 (2), 243-249

(1978.2.7 • 受付) 